\title{
Hypothalamo-gastrointestinal axis - role in food intake regulation
}

\author{
A. Wójcik-Gładysz ${ }^{1}$ and M. Szlis \\ The Kielanowski Institute of Animal Physiology and Nutrition Polish Academy of Sciences \\ Instytucka 3, 05-110 Jabłonna, Poland
}

KEY WORDS: hypothalamus, appetite regulation, orexigenic peptide, anorexigenic peptide, gastrointestinal hormones
Received: 7 August 2015

Revised: 26 February 2016

Accepted: 20 May 2016
${ }^{1}$ Corresponding author: e-mail: a.wojcik@ifzz.pl

\begin{abstract}
In homoeothermic vertebrates, one of the most important physiological mechanism concerns the maintenance of the homeostasis. The principal regulator of energy intake is situated in the central nervous system (CNS), where numerous central and peripheral hormones regulate the energy homeostasis. Neuronal pathways between some hypothalamic nuclei create the appetite regulating network in which orexigenic and anorexigenic circuits modify food intake and energy expenditure. In recent years, a serious problem concerning obesity and related diseases emerged in civilized societies. In order to resolve the issues of disturbances of food intake, it is necessary to understand mechanisms guiding neuroendocrine control of metabolic processes. Previous studies have focused on the role of gut peptides (now called gastrointestinal hormones) only in the regulation of the gastrointestinal tract function. Nowadays, it has become clear that gut hormones signalize via neural and endocrine mechanisms to the CNS to create the brain-gut axis which regulates energy homeostasis. This review is an attempt to summarize the knowledge about the hypothalamus-gastrointestinal axis. In the first part of the review the hypothalamic 'centre', engaged in the body energy homeostasis regulation and being the most important neuropeptide acting in this region, is presented. In the second one, the information about the origin, properties and some endocrine actions of the most important and best studied, in our opinion, gastrointestinal hormones regulating the food intake is reviewed. Detailed knowledge of the regulation of appetite mechanisms should be an opportunity to overcome an increasingly common problem of civilization - the epidemic of obesity.
\end{abstract}

\section{Introduction}

Animals and humans live in various and constantly changing environment. In homoeothermic vertebrates, the maintenance of the homeostasis under conditions of constantly changing external and internal stimuli affecting an organism is one of the most important problems. This state of relative equilibrium, like constant temperature, body hydration, electrolyte ratio, balance of energy resources, is essential for every living organism in order to ensure the proper conduct of physiological processes, particularly the rate of metabolic processes. In mammals, integration and processing of stimuli reaching the organism takes place in the central nervous system (CNS), especially in the hypothalamus. Hypothalamic neurons are involved in the sensing of circulating and local factors conveying information 
about the energy status of the organism. Integration of these signals leads to specific and coordinated physiological responses aimed at regulating energy balance through the modulation of appetite and energy expenditure.

Over the last 15 years many attempts have been made in order to understand peripheral signals regulating appetite and energy homeostasis. Paradoxically, because of increasing obesity problem, the knowledge about the interaction between gastrointestinal hormones and central nervous system concerning food intake modulation has greatly broadened. The results of extensive researches showed that the gastrointestinal tract is an active endocrine organ secreting numerous peptides known as gastrointestinal hormones now. Many of these peptides, including ghrelin, the only known orexigenic peripheral hormone, and numerous anorexigenic gut hormones, including obestatin, cholecystokinin (CCK), pancreatic polypeptide (PP), peptide YY (PYY), glucagon-like peptide (GLP)-1 and oxyntomodulin (OXM), have been shown to modulate food intake.

\section{The most important neuropeptides engaged in food intake regulation}

\section{Appetite regulating network}

Arcuate nucleus (ARC) is the neuronal formation which plays an essential role in the integration of signals regulating appetite. The nucleus is the palce of integration of many peripheral signals controlling food intake as well as area allowing to direct communication between CNS and peripheral hormones and also nutrient fluctuations in the bloodstream. Two subpopulations of neurons which synthetize the most important peptides controlling food intake and energy expenditure are localized in ARC. The first one acts as a feeding stimulator co-expressing neuropeptide Y (NPY) and agoutirelated peptide (AgRP).

NPY is one of the most abundant neuropeptides synthetized in different brain areas but the neurons involved in the appetite regulation are synthetized mainly in the ARC (Lopaschuk et al., 2010). The effects of NPY on energy balance regulation are mediated by postsynaptic Y1 and Y5 receptors, which belong to the class of $\mathrm{G}$ protein-coupled receptor subtypes (Nguyen et al., 2012). The NPY expression and release is related to changes in the organism energy status. NPY activity is reduced under feeding conditions, whereas the malnutrition stimulates its activity (Schneeberger et al., 2014). Moreover, intracerebroventricular (ICV) administration of NPY or its direct administration into specific hypothalamic nuclei increases food intake, whereas the administration of receptor selective antagonists ( $\mathrm{Y} 1$ and $\mathrm{Y} 5$ antagonists) or antisense oligonucleotides (Y5 receptor) reduces or inhibits food intake (Lopaschuk et al., 2010).

AgRP is co-expressed in NPY-expressing neurons (Cowley et al., 2003), but in contrast to NPY, AgRP is expressed only in the ARC. AgRP is an endogenous antagonist and inverse agonist of the melanocortin MC3 and MC4 receptors (MC3R, MC4R). Similar to NPY, the expression of AgRP is elevated during fasting and/or malnutrition conditions. On the other hand, the central administration of AgRP stimulates food intake and reduces energy expenditure resulting in increased obesity (Schneeberger et al., 2014).

The second subpopulation of neurons with anorexigenic properties co-expresses the cocaine- and amphetamine-regulated transcript (CART) and $\alpha$-melanocyte-stimulating hormone $(\alpha-\mathrm{MSH}$, a product of proopiomelanocortin (POMC) processing) (Coll et al., 2007).

CART was originally sequenced as a peptide with unknown function and was later confirmed to be the protein product of mRNA transcript up-regulated after short-term exposure to cocaine and amphetamine (Douglass et al., 1995). CART and POMC are co-expressed in neurons of ARC. The receptor for CART has not been identified yet, however in vitro studies strongly suggest that CART binds to a specific $\mathrm{G}$ protein-coupled receptor (Lin et al., 2011). Like other hypothalamic neuropeptides regulating energy homeostasis, its expression is responsive to the organism nutritional status. CART's expression is increased under feeding conditions, particularly as a consequence of the high-energy/high-fat food consumption (Wortley et al., 2004), and decreased under fasting conditions (Robson et al., 2002). Moreover, ICV infusion of CART results in the appetite reduction, while antibodies against CART reverse this effect (Schneeberger et al., 2014). It has been demonstrated, that polymorphisms of the CART gene, as well as alterations in CART protein level, are associated with human obesity (Lopaschuk et al., 2010).

POMC is the polypeptide precursor of the melanocortin family which includes $\alpha$-MSH (Germano et al., 2007), which is the most important anorexigenic peptide binding to MC3R and MC4R receptors expressed in PVN (Mercer et al., 2013). The levels of both POMC transcript and $\alpha-\mathrm{MSH}$ are increased under feeding conditions, while malnutrition reduces these levels. The central administration of MC4R agonist decreases food intake and thus the 
body weight, while infusion of the MC4R antagonist increases food consumption (Benoit et al., 2000). NPY/AgRP and CART/ $\alpha-M S H$ neurons localized in the ARC, project to other hypothalamic nuclei like paraventricular nucleus (PVN), ventromedial nucleus $(\mathrm{VMN})$ or dorsomedial nucleus $(\mathrm{DMN})$, which create the 'second-order' signalling structure converting information about energy homeostasis.

Summarizing, the subpopulation of NPY/AgRP and CART/ $\alpha-\mathrm{MSH}$ neurons, together with target 'second-order' neurons expressing the MC4R and MC3R, localized mainly in the PVN, create the 'appetite regulating network', essential for detection and integration of a number of peripheral signals allowing a precise control of appetite and energy expenditure. These neurons closely contact each other and project into other hypothalamic nuclei expressing MCRs and NPY receptors. Moreover, these two subpopulations of neurons express receptors for various peripheral hormonal signals. Orexigenic and anorexigenic neurons act in the opposite manner: NPY/AgRP as an endogenous MCR antagonist augments food intake and decreases energy expenditure, whereas $\alpha$-MSH as an endogenous MCR agonist attenuates appetite and enhances energy expenditure (Figure 1).

\section{Orexins}

Orexin A and B (or hypocretin 1 and 2) are produced from prepro-orexin in neurons localized mainly in the lateral hypothalamus area (LHA; Sakurai et al., 1998). Orexin neurons project into all hypothalamic nuclei engaged in food intake processes regulation: ARC, PVN, VMN and also

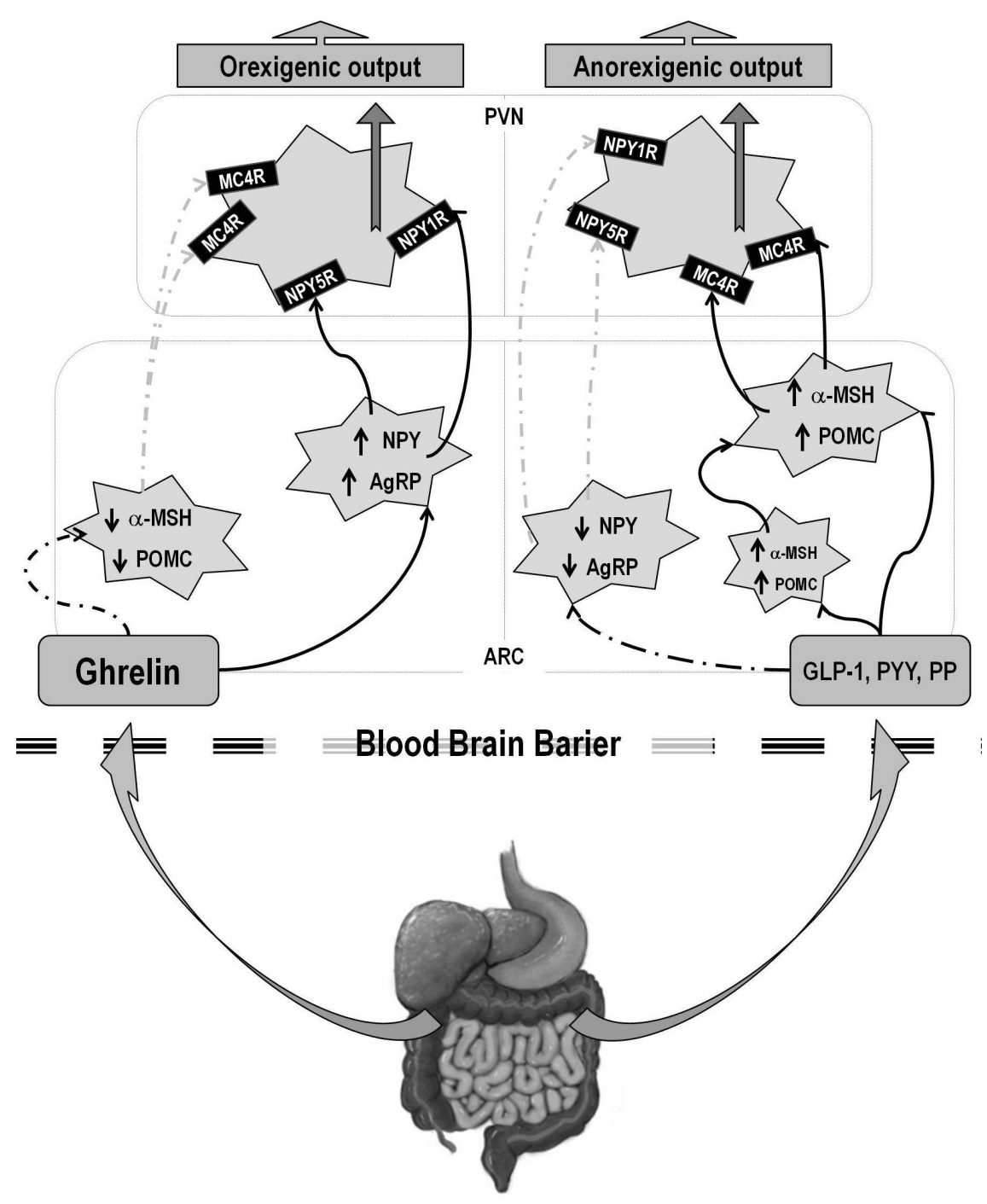

Figure 1. Hypothalamo-gastrointestinal axis scheme of food intake regulation mechanism. ARC - arcuate nucleus; PVN - paraventricular nucleus; POMC - proopiomelanocortin; a-MSH - a-melanocyte-stimulating hormone; NPY - neuropeptide Y; AgRP - agouti-related peptide; NPY5R5/1R - neuropeptide Y receptor types 5 or 1; MC4R - melanocortin receptor 4; GLP1 - glucagon-like peptide 1; PYY - peptide tyrosine tyrosine; PP - pancreatic polypeptide; solid arrows represent stimulatory effect, dotted arrows represent inhibitory effect 
nucleus of the solitary tract (NTS). Orexins act via two orexin receptors: orexin-1 receptor, located mainly in the VMN and characterized with high affinity for orexin A and orexin-2 receptor expressed in PVN and characterized with a similar affinity for both A and B types of orexin (Wynne et al., 2005). Orexin expression is significantly increased under fasting conditions. The central administration of orexins not only increases food intake, but also promotes behavioural responses to food reward and increases arousal (Cason et al., 2010). NPY, AgRP and $\alpha$-MSH terminals project into the LHA and contact with melaninconcentrating hormone $(\mathrm{MCH})$ or orexin expressing cells, in turn, central orexin neurons express NPY and leptin receptors and are thus able to integrate adiposity signals (Schneeberger et al., 2014).

\section{RFa/43RFa}

$26 \mathrm{RFa} / 43 \mathrm{RFa}$ is the latest identified peptide belonging to a new family of regulatory peptides RFamide peptides (43RFa is N-terminal extended form of 26RFa) (Chartrel et al., 2003). What is interesting, 26RFa is present in all vertebrates and its C-terminal domain (KGGFXFRF-NH2), responsible for its biological activity, has been fully conserved during evolution (Chartrel et al., 2011). This feature is characteristic for the neuropeptides performing the key functions in the organism, which confirms the important role of this 'new neuropeptide' (26RFa) as another orexigenic peptide involved in the food intake regulation at the hypothalamus level.

26RFa-expressing neurons display a discrete localization in the hypothalamic nuclei in all vertebrate species studied so far. They are localized in the areas involved in the regulation of food intake like ARC, PVN, VMN and LHA (Chartrel et al., 2006; Kampe et al., 2006). The effect of $26 \mathrm{RFa}$ in humans is mediated by GPR 103 receptor, which is a 7-transmembrane $G$ protein-coupled receptor (Chartrel et al., 2011). Two distinct forms of GPR103 receptor have been characterized in mice (designated GPR103A and GPR103B) and in rat (designated QRFP-r1 and QRFP-r2) (Kampe et al., 2006; Takayasu et al., 2006). The occurrence of two distinct GPR103 receptors seems to be specific to rodents, as the second gene encoding another form of GPR103 has not been identified in the genome of other vertebrate species (Chartrel et al., 2011). High expression of GPR103 mRNA was notably observed in hypothalamic and brainstem nuclei involved in the control of feeding behaviour, including VMN and DMN, PVN, ARC, LHA and NTS (Takayasu et al., 2006; Bruzzone et al., 2007).
The studies conducted on mice revealed that acute ICV administration of 26RFa evoked a dosedependent increase in food consumption (Chartrel et al., 2003; Takayasu et al., 2006). Moreover, expression of the $26 \mathrm{RFa}$ precursor was up-regulated in the hypothalamus of fasted mice (Takayasu et al., 2006). The 43RFa also stimulates food intake and its effect is even more pronounced than the effect of 26RFa (Moriya et al., 2006; Takayasu et al., 2006). In mice, chronic injection of $43 \mathrm{RFa}$ evoked a hyperphagic behaviour resulting in an increase of the body weight and fat mass but also in a decrease of the energy expenditure (Moriya et al., 2006). Fasting potentiates the orexigenic activity of $26 \mathrm{RFa}$. The effect of this neuropeptide was stronger when the animals were deprived of food the day before the injection (Chartrel et al., 2003; Lectez et al., 2009). 26RFa exerts orexigenic activity by enhancing expression of NPY which in turn inhibits the activity of POMC neurons via the activation of the Y1 and Y5 receptors (Lectez et al., 2009). Recent evidences indicate that $26 \mathrm{RFa}$ plays a key role in the mammals' hypothalamic regulation of food intake as an orexigenic factor and the $26 \mathrm{RFa} / \mathrm{GPR} 103$ system is involved in feeding behaviour defects such as anorexia nervosa and obesity.

\section{Gastrointestinal hormones}

As it was mentioned, an increasing problem of obesity caused almost exponential development of researches devoted to the mechanism of appetite regulation. The results of many studies have shown that the enteroendocrine cells distributed in the gastrointestinal tract constitute the largest endocrine organ in the body and are the source of various regulatory peptide hormones. The extension of the stomach walls and interactions between nutrients and the luminal wall of the intestine is the stimulus for the release of gut hormones like PYY, GLP-1 and OXM (Adrian et al., 1985; Le Quellec et al., 1992). Initially it was thought that the main role of the gut hormones is assigned to the peripheral control of gastrointestinal function regulation. Presently, there are numerous studies which prove the existence of gastrointestinal tract hormones and neuropeptides system co-regulating the body's energy balance. It is known that many of these peptides reduce food intake decreasing orexigenic signalling and increasing anorexigenic signalling in the nuclei of the hypothalamus (Batterham et al., 2006; Table 1).

This part of the review is dedicated to selected peripheral peptides which create the hypothalamogastrointestinal axis and modulate appetite and 
Table 1. The most important peptides involved in the hypothalamogastrointestinal axis

\begin{tabular}{|c|c|c|c|}
\hline Hormone & $\begin{array}{l}\text { Site } \\
\text { of synthesis }\end{array}$ & Receptor & $\begin{array}{l}\text { Effect } \\
\text { on food } \\
\text { intake }\end{array}$ \\
\hline Neuropeptide Y (NPY) & Hypothalamus & $\begin{array}{l}\text { Y1 } \\
\text { Y5 }\end{array}$ & Increase \\
\hline Agouti-related protein (AgRP) & Hypothalamus & $\begin{array}{l}\text { MC3R } \\
\text { MC4R }\end{array}$ & Increase \\
\hline $\begin{array}{l}\text { Cocaine- and amphetamine- } \\
\text { regulated transcript (CART) }\end{array}$ & Hypothalamus & $\begin{array}{l}\text { MC3R } \\
\text { MC4R }\end{array}$ & Decrease \\
\hline Proopiomelanocortin (POMC) & Hypothalamus & $\begin{array}{l}\text { MC3R } \\
\text { MC4R }\end{array}$ & Decrease \\
\hline $26 \mathrm{RFa}$ & Hypothalamus & GPR104 & Increase \\
\hline Ghrelin & Stomach A-cells & GHSR1a & Increase \\
\hline Obestatin & Stomach B-cells & $\begin{array}{l}\text { GPR34* } \\
\text { GLP-1R* }\end{array}$ & Decrease \\
\hline Peptide tyrosine tyrosine (PYY) & Intestinal L-cells & $Y 2 R$ & Decrease \\
\hline Pancreatic polypeptide (PP) & Pancreas/colon & Y4R & Decrease \\
\hline Glucagon-like peptide-1 (GLP-1) & ) Intestinal L-cells & GLP-1R & Decrease \\
\hline Oxyntomodulin (OXM) & Intestinal L-cells & GLP-1R* & Decrease \\
\hline Nesfatin-1 & $\begin{array}{l}\text { Hypothalamus/ } \\
\text { stomach }\end{array}$ & * & Decrease \\
\hline Neuromedin (NMU) & $\begin{array}{l}\text { Hypothalamus/ } \\
\text { stomach }\end{array}$ & $\begin{array}{l}\text { NMUR1 } \\
\text { NMUR2 }\end{array}$ & Decrease \\
\hline
\end{tabular}

Y1, Y5 - neuropeptide Y receptor 1 and 5; MC3R, MC4R - melanocortin receptor 3 and 4; GHSR - growth hormone secretagogue receptor 1a; Y2R, Y4R-Y2 and Y4 receptor; GLP-1R - glucagon-like peptide-1 receptor; NMUR1, NMUR2 - neuromedin U receptor 1 and $2 ;{ }^{*}$ - unidentified

metabolic rate of the body. In our review we focused on the best examined as well as recently discovered hormones of the gastrointestinal tract, which from our point of view, play the crucial role in the appetite regulation processes. An expanding knowledge concerning the mechanisms of these hormones action creates the possibility to use them or their synthetic equivalents in the treatment of problems associated with morbid obesity.

\section{Ghrelin}

Ghrelin is a 28 -amino acid peptide derived from pre-proghrelin. It is secreted primarily in the stomach from the X/A cells of the gastric oxyntic gland but also in the other part of the gastrointestinal tract like the small intestine (Date et al., 2000). For the first time ghrelin was identified in 1999 as the endogenous ligand of the growth hormone secretagogue receptor 1a (GHS-R1a), which was subsequently renamed on the ghrelin receptor (Kojima et al., 1999). The presence of an 8- $n$ acyl group at the serine in position 3 is a unique feature of ghrelin, resulting from posttranslational modification. Although circulating ghrelin is found in both acylated and desacylated forms (Hosoda et al., 2003), only acylated ghrelin has ability to bind to the $G$ protein-coupled receptor, GHS-R1a, and to penetrate the blood-brain barrier (BBB) (Pan et al., 2006). GHS-R1a has significant baseline constitutive activity and is highly expressed throughout the whole hypothalamus area (Zigman et al., 2006). Ghrelin is another modulator of energy balance, with crucial role in appetite regulation, fuel substrate preference, body weight and glucose homeostasis. It is worth emphasizing, that ghrelin, in contrary to many other peripheral hormones, exhibits a powerful orexigenic actions (Schneeberger et al., 2014). Thereby, the level of ghrelin in plasma is reduced after the meal. In rodents, both central and peripheral administration of ghrelin have been shown to promote feed intake, adiposity and body weight gain (Nakazato et al., 2001). Circulating ghrelin level increases with fasting and falls with nutrient ingestion in rodents and humans (Nakazato et al., 2001; Zigman et al., 2006). Moreover, initiating meals voluntarily in human subjects the pre-prandial peaks and post-prandial suppression of ghrelin levels were demonstrated, which suggests that ghrelin plays a role in meal initiation (Cummings et al., 2001). Also in humans, peripheral ghrelin administration increases appetite and food intake; on the other hand, circulating ghrelin level increases in the states of inadequate nutrition (Gibson et al., 2010).

The NPY/AgRP neurons localized in the ARC appears to be the primary targets for hypothalamic ghrelin and this population of neurons is essential for the mediation of the orexigenic effects of ghrelin (Cowley et al., 2003; Castañeda et al., 2010). The presence of the GHS-R1a receptor (specific for acylated form of ghrelin) in the ARC nucleus has been stated in studies conducted on rats. Moreover, the central and peripheral administration of ghrelin enhances transcription factor c-Fos expression in the ARC neurons (Hewson and Dickson, 2000) and also in other nuclei involved in the appetite control, including the PVN, DMN and LHA, as well as in the area postrema (AP) and NTS in the brainstem (Lawrence et al., 2002). In the ARC, in turn, ghrelin stimulates NPY and AgRP transcription, as well as promotes release of these both orexigenic-peptides in the PVN (Schneeberger et al., 2014). Consequently, the central actions of ghrelin lead to increased food intake and body weight gain (Muccioli et al., 2011; Figure 1).

Plasma ghrelin level is reduced after gastric bypass surgery, possibly due to diversion of nutrients and partialy by suppression of ghrelin synthesis (Cummings et al., 2002). This fall in circulating ghrelin level has been suggested to play a role in 
mediating the appetite reduction and weight loss observed following this procedure. Unfortunately, so far bariatric surgery is the most effective treatment for morbid obesity.

\section{Obestatin}

Obestatin, 23-amino acid hormone discovered in 2005, originates from the same precursor peptide as ghrelin, named preproghrelin (Zhang et al., 2005). Both of these peptides arise as a result of posttranslational processing of the common precursor preproghrelin, but they exhibit different physiological activity. Ghrelin is an orexigenic peptide, which stimulates appetite, while obestatin exhibits an anorexigenic effect through food intake inhibition. Originally, obestatin has been isolated from cells located in the mucosa of the rat stomach fundus, but the subsequent studies confirmed its localization also in other tissues like duodenum, jejunum, colon, pancreas, liver, mammary glands, testes (Leydig cells), lungs, saliva and blood plasma (Zhang et al., 2005; Dun et al., 2006). This is another peripheral hormone involved in the functioning of the complex neurohormonal network regulating food intake and, similarly to ghrelin, it is able to penetrate the BBB (Pan et al., 2006).

The knowledge on the obestatin functioning in the CNS is fragmentary and often contradictory, so its physiological role and precise mechanism of action are still not fully understood. This is the result of its rapid degradation (half-life of obestatin in the blood plasma is about $22 \mathrm{~min}$ ), as well as the lack of an identified receptor (Pan et al., 2006; Granata et al., 2008). Acute administration of obestatin in the high doses inhibited food consumption both in mice, and in lean and fatty Zucker rats (Lagaud et al., 2007). On the other hand, in numerous comprehensive studies performed on rodents, no significant effect of peripherally or centrally administered obestatin was observed on food intake, energy expenditure or body weight with either acute or chronic treatment (for review see Lopaschuk et al., 2010).

\section{Peptide tyrosine tyrosine (PYY)}

PYY is a 36-amino acid peptide which belongs to the 'PP-fold' family. It is secreted mainly by the entero-endocrine L-cells of the intestinal epithelium of the small and large intestine, and the colon in response to nutrient ingestion (Adrian et al., 1985). There are known two endogenous forms of this peptide: PYY 1-36 and PYY 3-36, but the latter is the most abundant in the blood circulation and has ability to penetrate the BBB (Nonaka et al., 2003). These two forms exert effects through the family of receptors for neuropeptide Y. PYY 1-36 binds to all of the Y receptors, while PYY 3-36 binds with the high affinity to the Y2 receptor subtype (Y2R) (Larhammar, 1996). Circulating PYY level decreases under fasting conditions and rises post-prandially in proportion to caloric intake (Batterham et al., 2003a), especially after the protein rich meals (Batterham et al., 2006). Anorexigenic action of PYY 3-36 is mediated via the inhibition of Y2 receptor expressed on the neurons localized in the ARC (Scott et al., 2005). In rodents, both the central and peripheral PYY 3-36 administrations increase $\alpha-\mathrm{MSH}$ and reduce NPY release in this area, which consequently reduces appetite and body weight in a dose-dependent manner (Batterham et al., 2003a). Although, there are also studies showing the inhibitory effect of PYY 3-36 on POMC neurons activity, suggesting that POMC is not critical for PYY 3-36 action on food intake regulation. Moreover, the bilateral total truncal vagotomy or transections of the brainstem-hypothalamic pathways in rodents (Abbott et al., 2005) abolishes the effects of peripheral administration of PYY 3-36 on food intake and the activation of ARC feeding command neurons (Abbott et al., 2005; Koda et al., 2005), which suggests the role of the vagal brainstem pathway in the actions of circulating PYY 3-36.

\section{Pancreatic polypeptide (PP)}

$\mathrm{PP}$ is 36-amino acid peptide that is another member of the 'PP-fold' family. It is synthesized primarily by $\mathrm{F}$ cells (PP cells) in the pancreatic islets of Langerhans; however, the presence of the PP is stated almost in the entire gastrointestinal tract (Adrian et al., 1976). Although PP binds to all the members of the Y receptor family, its anorexigenic effect is mediated mainly through the Y4 receptor subtype (Michel et al., 1998). The Y4 receptor mRNA has been localized in the appetite-regulating areas of the brainstem, notably in the AP and in the ARC of the hypothalamus (Parker and Herzog, 1999). Furthermore, results of studies conducted on mice revealed that the peripheral administration of PP inhibits the activity of neurons in the areas responsible for the central control of appetite like the ARC, VMH and PVN (Hankir et al., 2011). In the gastrointestinal area PP is responsible for the regulation of the gallbladder motility and pancre-atic secretion (Adrian et al., 1976). PP, as another anorexigenic hormone, is secreted after a meal proportionally to the amount of consumed calories. Circulating level of PP rises after meals and remains elevated for up to $6 \mathrm{~h}$ post-prandially (Batterham et al., 2003b). Peripherally-administered PP reduces food intake and the body weight in both rodents and humans. In fasted 
mice, acute intraperitoneal injection of PP reduces food intake (Asakawa et al., 2003), and this effect remains apparent for $24 \mathrm{~h}$ after injection. Chronic administration of PP results in the reduction of the body weight gain and an increased spontaneous locomotor activity in mice (Asakawa et al., 2003; Liu et al., 2008). The anorexigenic action of PP has been observed also in humans. It was demonstrated that intravenous infusion of PP reduces appetite in lean humans and that this food intake inhibition persists for $24 \mathrm{~h}$ after infusion (Batterham et al., 2003b).

\section{Glucagon-like peptide-1 (GLP-1)}

GLP-1 is a 29(30)-amino acid peptide is the product of preproglucagon molecule cleavage, which is synthetized by the entero-endocrine L-cells in the distal ileum and colon. It is also expressed in hypothalamus areas involved in the appetite regulation. In the circulation, there are two isoforms of GLP-1: GLP-1 (7-37) and GLP-1 (7-36). GLP-1 is released into circulation in proportion to the calories intake. Its level can increase up to 20 -fold in response to food intake, while under fasting conditions it is reduced (Drucker and Nauck, 2006). The effect of GLP-1 is mediated by GLP-1 receptor. The GLP-1R is expressed in the ARC, on the POMC-expressing neurons, which confirms the participation of GLP-1 in the control of energy balance (Tang-Christiansen et al., 2001).

On the periphery, GLP-1 stimulates the glucoseinduced insulin synthesis and secretion, maintains mass of pancreatic B cells and slows down stomach emptying (Drucker and Nauck, 2006). Moreover, a number of studies have shown that GLP-1 crosses the BBB and therefore peripheral administration of GLP-1 may act at the hypothalamus level to enhance satiety, and to reduce food intake and weight gain in rats (Tang-Christiansen et al., 2001). Also in healthy and obese humans, the intravenous administration of GLP-1 reduces food intake in a dose dependent manner (Verdich et al., 2001). The results of studies on rodents have revealed that the effect of GLP-1 on the suppression of appetite is abolished by vagotomy which suggests that GLP-1 can act via vagal and brainstem pathways (Abbott et al., 2005; Barrera et al., 2011).

GLP-1 is one of the strongest anorexigenic factors (even its microinjection inhibits food intake in fasted animals), therefore, it has been intended to use it in the treatment of obesity. However, its very short halflife (about $2-5 \mathrm{~min}$ ) and very rapid inactivation in the peripheral blood by the dipeptidyl peptidase- 4 (DPP-IV) enzyme, exclude GLP-1 from the therapy (Filipek, 2010).
The researches in the field of the obesity and diabetes treatment resulted in the development of knowledge on the availability of GLP-1 synthetic analogues. There are compounds with a similar structure but with a significantly prolonged half-life in comparison to GLP-1. Exenatide, which is used in the treatment of type II diabetes, is the most known from this group (Filipek, 2010). The liraglutide is the first long-acting analogue of GLP-1 obtained by modifying the structure of the GLP-1, which resulted in increased resistance to degradation by enzyme DPP-IV and gave approximately a 13-hour half-life. Currently tested analogues (drugs) such as exenatide LAR, are prepared as slow-released microcapsules which prolongs the blood half-life up to 10 days. Another tested analogue with $93 \%$ homology with the human GLP-1 is taspoglutide, in which zinc is used to slow down the absorption and extended its half-life to 7 days (Filipek, 2010; Dejgard, 2015; Xu, 2015).

\section{Oxyntomodulin (OXM)}

OXM is a 37 -amino acid peptide that is another product of the preproglucagon precursor molecule. OXM, similarly to GLP-1, is released from L cells of the intestine in the response to ingested food and in proportion to calories intake (Le Quellec et al., 1992). The results of some experiments showed that anorexigenic effect of OXM is mediated by, at least, two receptors: GLP-1 receptor and the second not identified one (Dakin et al., 2004). On the periphery, OXM is responsible for the inhibition of the gastric emptying and reduction of gastric acid secretion (Schjoldager et al., 1989). The results of some studies on rodents have revealed that administration of OXM reduces food intake and in consequence decreases weight gain and also causes an increase in energy expenditure (Dakin et al., 2004). The anorexigenic effect of OXM has been observed also in humans. Intravenous administration of OXM reduces food intake and increases energy expenditure both in healthy and obese human (Wynne et al., 2006). OXM, like GLP-1, is inactivated by enzyme DPP-IV; hence OXM analogues resistant to DPP-IV degradation are being now developed as potential obesity treatments (Druce et al., 2009).

\section{Cholecystokinin (CCK)}

CCK was the first gut hormone that was shown to have anorexigenic effect in rats (Gibbs et al., 1973) and humans (Kissileff et al., 1981). It is secreted post-prandially by the entero-endocrine I-cells in the mucosal epithelium of the small intestine (Gibbs et al., 1973). In the gastrointestinal tract, CCK 
delays gastric emptying, stimulates pancreatic enzyme release and stimulates gallbladder contraction. Depending on the post-translational modification, there are several forms of CCK, with a different number of amino acids (e.g., CCK-58, CCK-33, CCK-8) (Reeve et al., 1994). In the CNS and in the peripheral tissues two types of CCK receptor have been identified. CCK1 receptor has been identified in the NTS, AP and DMN, i.e. in areas involved in the food intake regulation (Moran and Kinzig, 2004). In peripheral tissues, CCK 1 receptor is present on vagal afferent nerve fibres innervating the gut, in the pancreas and gallbladder. CCK-2 receptor is expressed in the cerebral cortex, hypothalamus, vagal nerve, spinal cord and gastric mucosa (Moran and Kinzig, 2004). The anorexigenic effects of CCK are mainly mediated via CCK1 receptor on vagal afferent fibres that project into the NTS (Moran et al., 1997). CCK is released in response to saturated fatty acids, long chain fatty acids and products from protein digestion after the meal (Liddle et al., 1985; Rehfeld et al., 2003). It was demonstrated that peripheral administration of CCK decreases food intake by diminishing the size and duration of individual meal, which suggests that $\mathrm{CCK}$ is responsible rather for short-time regulation of appetite. As well as restraining appetite, $\mathrm{CCK}-8$ elicits the complete behavioural sequence of the satiety in rats, including grooming, decreased locomotor activity and apparent sleep (Lo et al., 2014). Unfortunately, long-term administration of CCK in humans causes the nausea and tachyphylaxis phenomenon, which limits this hormone usage in the treatment for obesity (Covasa et al., 2001).

\section{Nesfatin-1}

Discovered in 2006 nesfatin-1 is a 82-amino acid hormone which exerts a strong anorectic action. It is derived from the precursor protein nucleobindin 2 (NUCB2) which expression has been demonstrated at both, gene and protein level in regions involved in food intake regulation such as ARC, PVN and LHA (Oh-I et al., 2006). In these areas NUCB2/nesfatin-1 is often co-expressed with other peptides involved in the appetite regulation, like CART, $\alpha$-MSC or NPY (Okere et al., 2010). Then, the presence of mRNA for NUCB2 has been also established in the many peripheral tissues like stomach or pancreas (GoebelStengel et al., 2011). In the gastric oxyntic mucosa a 10-fold higher level of the NUCB2/nesfatin-1 has been found then in the brain tissues (Goebel-Stengel et al., 2011). Despite the anorexic properties of the nesfatin-1, which have been experimentally demonstrated, the mechanism of its action remains poorly understood, partly because the nesfatin-1 receptor has not been identified yet.

The results of studies conducted on rodents have revealed that ICV administration of the nesfatin-1 is able to decrease food intake and its chronic administration results in the reduction of weight gain and accumulated adipose tissue (Oh-I et al., 2006). Moreover it has been documented, that the anorexigenic effect of nesfatin-1 is due to the induction of satiation (reduction of meal size) as well as satiety (decreased meal frequency associated with prolonged inter-meal intervals) (Goebel et al., 2011). In the gastrointestinal tract nesfatin-1, in both rats and mice, is responsible for the retardation of gastric emptying and suppression of gastro-duodenal motility in mice (Goebel-Stengel et al., 2011).

Currently, it has been demonstrated that, the mechanisms of nesfatin-1's anorexigenic action is independent of leptin signalling in the hypothalamus (Maejima et al., 2009). Because human obesity shows a conditioned resistance to leptin, a recognition of bioactive molecules that exert anorexia independently from leptin signalling is very important (Shimizu et al., 2009). Taking into account this information, detailed understanding of the nesfatin-1 cellular mechanism of anorexigenic action, would be invaluable to future development of nesfatin-1 analogues as anti-obesity drugs.

\section{Neuromedin U (NMU)}

NMU is a highly conserved peptide that has been implicated in energy homeostasis and a wide variety of other physiological processes (Mitchell et al., 2009). It is expressed in the gastrointestinal tract (Ballesta et al., 1988) and also in the brain, especially in the hypothalamus (Fuji et al., 2000). The physiological effect of NMU is mediated by two G protein-coupled receptors NMUR1 and NMUR2 (Raddatz et al., 2000). NMUR1 is expressed predominantly in peripheral tissues, such as intestine, pancreas, uterus, lungs and kidney, but expression of NMUR2 is limited to areas of the brain with high level observed in the hypothalamus, particularly in the ARC and PVN (Raddatz et al., 2000; Graham et al., 2003). The biological role of NMU in peripheral tissues concerns the regulation of intestinal motility and smooth muscle contractility in blood vessels and the uterus (Minamino et al., 1985). Then the results of studies conducted on mice have shown that transgenic mice lacking NMU are obese and have reduced energy expenditure (Hanada et al., 2004). On the other hand mice that overexpress NMU showed reduced food intake and weight loss, even when they were fed high-fat food (Kowalski et al., 2005). Likewise in 
humans, mutations in NMU gene have been linked to body weight gain and obesity (Deng et al., 2002).

Acute central administration of NMU reduces food consumption in both fasted and fed ad libitum rodents as well as increases the locomotor activity and core body temperature (Howard et al., 2000; Nakazato et al., 2000). In has been showed that NMU injections induce the immediate increase in the c-Fos expression in the ARC and PVN (Ozaki et al., 2002). Moreover the NMU acting through a NMUR2 receptor causes stimulation of POMC mRNA expression (Peier et al., 2011). Also acute and chronic peripheral administration of NMU in mice are resulted in a significant reduction in food intake and body weight although this action have been mediated by NMUR1 receptors expressed in peripheral tissues (Peier et al., 2011). Additionally, NMU increases body temperature, metabolic rate and elevations in GLP-1 (Peier et al., 2011). These data suggest that development of NMUR1-selective agonists may provide a useful new approach to the treatment of diabetes and obesity. This seems particularly important, considering the fact, that the anorexigenic effect of NMU is independent of the leptin signalling pathway.

To date there is no information about the ability of NMU to penetrate the BBB and its exact action mechanism is not fully known. Some results suggest, that its anorectic effect depends, at least in part, on signalling via vagal innervation of the abdomen, and is not the result of direct action in the CNS (Peier et al., 2011). Additionally, peripheral administration of NMU caused a decrease in the expression of NPY, AgRP and, which is surprising, also POMC peptides (Peier et al., 2011).

\section{Conclusions}

Currently, more than 30 peptides involved in the regulation of food intake have been identified. These peptides signalize via neural and endocrine mechanisms to the CNS to create the brain-gut axis which regulates the processes related to maintaining a metabolic homeostasis of the organism. Some of these compounds, like NPY, AgRP and $\alpha$-MSH, play a crucial role in the processes, others, such as PYY, GLP-1, have rather modulatory role. Many neural pathways within the gut-brain system have excitable properties, while others exert an antagonistic effect. These processes can be modulated simultaneously at the level of the peripheral tissues, through the level of the pituitary gland, until the neural pathways within the nuclei of the hypothalamus. Summarizing, hypothalamo-gastrointestinal tract axis creates the system, whose function is to ensure the internal equilibrium necessary for optimal action of the most important fundamental processes of life.

Moreover, probably some of described above hormones may play an important role in food intake disorders in the future. Currently, the only effective in morbid obesity treatment is gastrointestinal bypass surgery, often causing serious health complications. In the future elucidation of the mechanisms of energy homeostasis disorders will create the possibility of innovative treatments basing on the peripheral hormones like OXM, PYY or ghrelin, and central neuropeptides like NPY or 26RFa, so the therapy could be adapted to the individual patient and performed without surgical intervention.

\section{References}

Abbott C.R., Monteiro M., Small C.J., Sajedi A., Smith K.L., Parkinson J.R., Ghatei M.A., Bloom S.R., 2005. The inhibitory effects of peripheral administration of peptide $Y Y_{3-36}$ and glucagonlike peptide-1 on food intake are attenuated by ablation of the vagal-brainstem-hypothalamic pathway. Brain Res. 1044, 127-131

Adrian T.E., Bloom S.R., Bryant M.G., Polak J.M., Heitz P.H., Barnes A.J., 1976. Distribution and release of human pancreatic polypeptide. Gut 17, 940-944

Adrian T.E., Ferri G.L., Bacarese-Hamilton A.J., Fuessl H.S., Polak J.M., Bloom S.R., 1985. Human distribution and release of a putative new gut hormone, peptide YY. Gastroenterology 89, 1070-1077

Asakawa A., Inui A., Yuzuriha H., Ueno N., Katsuura G., Fujimiya M., Fujino M.A., Niijima A., Meguid M.M., Kasuga M., 2003. Characterization of the effects of pancreatic polypeptide in the regulation of energy balance. Gastroenterology 124, 1325-1336

Ballesta J., Carlei F., Bishop A.E., Steel J.H., Gibson S.J., Fahey M., Hennessey R., Domin J., Bloom S.R., Polak J.M., 1988. Occurrence and developmental pattern of neuromedin U-immunoreactive nerves in the gastrointestinal tract and brain of the rat. Neuroscience 25, 797-816

Barrera J.G., Sandoval D.A., D'Alessio D.A., Seeley R.J., 2011. GLP-1 and energy balance: an integrated model of short-term and long-term control. Nat. Rev. Endocrinol. 7, 507-516

Batterham R.L., Cohen M.A., Ellis S.M., Le Roux C.W., Withers D.J., Frost G.S., Ghatei M.A., Bloom S.R., 2003a. Inhibition of food intake in obese subjects by peptide $Y Y_{3-36}$. N. Engl. J. Med. 349, 941-948

Batterham R.L., Heffron H., Kapoor S., Chivers J.E., Chandarana K., Herzog H., Le Roux C.W., Thomas E.L., Bell J.D., Withers D.J., 2006. Critical role for peptide $Y Y$ in protein-mediated satiation and body-weight regulation. Cell Metab. 4, 223-233

Batterham R.L., Le Roux C.W., Cohen M.A., Park A.J., Ellis S.M., Patterson M., Frost G.S., Ghatei M.A., Bloom S.R., 2003b. Pancreatic polypeptide reduces appetite and food intake in humans. J. Clin. Endocrinol. Metab. 88, 3989-3992

Benoit S.C., Schwartz M.W., Lachey J.L. et al., 2000. A novel selective melanocortin-4 receptor agonist reduces food intake in rats and mice without producing aversive consequences. J. Neurosci. 20, 3442-3448 
Bruzzone F., Lectez B., Alexandre D. et al., 2007. Distribution of 26RFa binding sites and GPR103 mRNA in the central nervous system of the rat. J. Comp. Neurol. 503, 573-591

Cason A.M., Smith R.J., Tahsili-Fahadan P., Moorman D.E., Sartor G.C., Aston-Jones G., 2010. Role of orexin/hypocretin in reward-seeking and addiction: implications for obesity. Physiol. Behav. 100, 419-428

Castañeda T.R., Tong J., Datta R., Culler M., Tschöp M.H., 2010. Ghrelin in the regulation of body weight and metabolism. Front. Neuroendocrinol. 31, 44-60

Chartrel N., Alonzeau J., Alexandre D., Jeandel L., Alvear-Perez R., Leprince J., Boutin J., Vaudry H., Anouar Y., Llorens-Cortes C., 2011. The RFamide neuropeptide 26RFa and its role in the control of neuroendocrine functions. Front. Neuroendocrinol. 32, 387-397

Chartrel N., Bruzzone F., Leprince J. et al., 2006. Structure and functions of the novel hypothalamic RFamide neuropeptides $\mathrm{R}-\mathrm{RFa}$ and $26 \mathrm{RFa}$ in vertebrates. Peptides 27, 1110-1120

Chartrel N., Dujardin C., Anouar Y. et al., 2003. Identification of 26RFa, a hypothalamic neuropeptide of the RFamide peptide family with orexigenic activity. Proc. Nat. Acad. Sci. USA 100, $15247-15252$

Coll A.P., Farooqi I.S., O'Rahilly S., 2007. The hormonal control of food intake. Cell 129, 251-262

Covasa M., Marcuson J.K., Ritter R.C., 2001. Diminished satiation in rats exposed to elevated levels of endogenous or exogenous cholecystokinin. Am. J. Physiol. Regul. Integr. Comp. Physiol. 280, R331-R337

Cowley M.A., Smith R.G., Diano S. et al., 2003. The distribution and mechanism of action of ghrelin in the CNS demonstrates a novel hypothalamic circuit regulating energy homeostasis. Neuron 37, 649-661

Cummings D.E., Purnell J.Q., Frayo R.S., Schmidova K., Wisse B.E., Weigle D.S., 2001. A preprandial rise in plasma ghrelin levels suggests a role in meal initiation in humans. Diabetes 50 , 1714-1719

Cummings D.E., Weigle D.S., Frayo R.S., Breen P.A., Ma M.K., Dellinger E.P., Purnell J.Q., 2002. Plasma ghrelin levels after diet-induced weight loss or gastric bypass surgery. N. Engl. J. Med. 346, 1623-1630

Dakin C.L., Small C.J., Batterham R.L., Neary N.M., Cohen M.A., Patterson M., Ghatei M.A., Bloom S.R., 2004. Peripheral oxyntomodulin reduces food intake and body weight gain in rats. Endocrinology 145, 2687-2695

Date Y., Kojima M., Hosoda H., SawaguchiA., Mondal M.S., Suganuma T., Matsukura S., Kangawa K., Nakazato M., 2000. Ghrelin, a novel growth hormone-releasing acylated peptide, is synthesized in a distinct endocrine cell type in the gastrointestinal tracts of rats and humans. Endocrinology 141, 4255-4261

Dejgaard T.F., 2015. Efficacy and safety of liraglutide added to insulin in type 1 diabetes: The LIRA-1 trial. $75^{\text {th }}$ Scientific Sessions of the American Diabetes Association (ADA), Session 'Updates on GLP-1 Agonists', June 5 - 9, 2015, Boston, MA (USA) http://professional2.diabetes.org/presentations_details. aspx? congress $=238$

Deng H.-W., Deng H., Liu Y.-J. et al., 2002. A genomewide linkage scan for quantitative-trait loci for obesity phenotypes. Am. J. Hum. Genet. 70, 1138-1151

Douglass J., McKinzie A.A., Couceyro P., 1995. PCR differential display identifies a rat brain mRNA that is transcriptionally regulated by cocaine and amphetamine. J. Neurosci. 15, 2471-2481
Druce M.R., Minnion J.S., Field B.C.T., Patel S.R., Shillito J.C., Tilby M., Beale K.E.L., Murphy K.G., Ghatei M.A., Bloom S.R., 2009. Investigation of structure-activity relationships of oxyntomodulin (Oxm) using Oxm analogs. Endocrinology 150, 1712- 1721

Drucker D.J., Nauck M.A., 2006. The incretin system: glucagon-like peptide-1 receptor agonists and dipeptidyl peptidase-4 inhibitors in type 2 diabetes. Lancet 368, 1696-1705

Dun S.L., Brailoiu G.C., Brailoiu E., Yang J., Chang J.K., Dun N.J., 2006. Distribution and biological activity of obestatin in the rat. J. Endocrinol. 191, 481-489

Filipek B., 2010. Place of incretin mimetics and dipeptidyl peptidase-4 inhibitors in the treatment of type 2 diabetes. Farm. Pol. 66, $55-61$

Fuji R., Hosoya M., Fukusumi S., Kawamata Y., Habata Y., Hinuma S., Onda H., Nishimura O., Fujino M., 2000. Identification of neuromedin $\mathrm{U}$ as the cognate ligand of the orphan $\mathrm{G}$ proteincoupled receptor FM-3. J. Biol. Chem. 275, 21068-21074

Germano C.M.R., de Castro M., Rorato R., Laguna M.T.C., AntunesRodrigues J., Elias C.F., Elias L.L.K., 2007. Time course effects of adrenalectomy and food intake on cocaine- and amphetamine-regulated transcript expression in the hypothalamus. Brain Res. 1166, 55-64

Gibbs J., Young R.C., Smith G.P., 1973. Cholecystokinin decreases food intake in rats. J. Comp. Physiol. Psychol. 84, 488-495

Gibson W., Liu J., Gaylinn B., Thorner M.O., Meneilly G.S., Babich S.L., Thompson D., Chanoine J.P., 2010. Effects of glucose and insulin on acyl ghrelin and desacyl ghrelin, leptin, and adiponectin in pregnant women with diabetes. Metabolism 59, 841-847

Goebel M., Stengel A., Wang L., Taché Y., 2011. Central nesfatin-1 reduces the nocturnal food intake in mice by reducing meal size and increasing inter-meal intervals. Peptides 32, 36-43

Goebel-Stengel M., Wang L., Stengel A., Taché Y., 2011. Localization of nesfatin-1 neurons in the mouse brain and functional implication. Brain Res. 1396, 20-34

Graham E.S., Turnbull Y., Fotheringham P., Nilaweera K., Mercer J.G., Morgan P.J., Barrett P., 2003. Neuromedin U and neuromedin $U$ receptor-2 expression in the mouse and rat hypothalamus: effects of nutritional status. J. Neurochem. 87, 1165-1173

Granata R., Settanni F., Gallo D. et al., 2008. Obestatin promotes survival of pancreatic $\beta$-cell and human islets and induces expression of genes involved in the regulation of $\beta$-cell mass and function. Diabetes 57, 967-979

Hanada R., Teranishi H., Pearson J.T. et al., 2004. Neuromedin U has a novel anorexigenic effect independent of the leptin signaling pathway. Nature Med. 10, 1067-1073

Hankir M.K., Parkinson J.R.C., Minnion J.S., Addison M.L., Bloom S.R., Bell J.D., 2011. Peptide $Y_{3-36}$ and pancreatic polypeptide differentially regulate hypothalamic neuronal activity in mice in vivo as measured by manganese-enhanced magnetic resonance imaging. J. Neuroendocrinol. 23, 371-380

Hewson A.K., Dickson S.L., 2000. Systemic administration of ghrelin induces Fos and Egr-1 proteins in the hypothalamic arcuate nucleus of fasted and fed rats. J. Neuroendocrinol. 12, 1047-1049

Hosoda H., Kojima M., Mizushima T., Shimizu S., Kangawa K., 2003. Structural divergence of human ghrelin. Identification of multiple ghrelin-derived molecules produced by post-translational processing. J. Biol. Chem. 278, 64-70

Howard A.D., Wang R., Pong S.-S. et al., 2000. Identification of receptors for neuromedin $\mathrm{U}$ and its role in feeding. Nature 406 , 70-74 
Kampe J., Wiedmer P., Pfluger P.T. et al., 2006. Effect of central administration of QRFP (26) peptide on energy balance and characterization of a second QRFP receptor in rat. Brain Res. $1119,133-149$

Kissileff H.R., Pi-Sunyer F.X., Thornton J., Smith G.P., 1981. C-terminal octapeptide of cholecystokinin decreases food intake in man. Am. J. Clin. Nutr. 34, 154-160

Koda S., Date Y., Murakami N. et al., 2005. The role of the vagal nerve in peripheral $\mathrm{PYY}_{3-36}$-induced feeding reduction in rats. Endocrinology 146, 2369-2375

Kojima M., Hosoda H., Date Y., Nakazato M., Matsuo H., Kangawa K., 1999. Ghrelin is a growth-hormone-releasing acylated peptide from stomach. Nature 402, 656-660

Kowalski T.J., Spar B.D., Markowitz L. et al., 2005. Transgenic overexpression of neuromedin $U$ promotes leanness and hypophagia in mice. J. Endocrinol. 185, 151-164

Lagaud G.J., Young A., Acena A., Morton M.F., Barrett T.D., Shankley N.P., 2007. Obestatin reduces food intake and suppresses body weight gain in rodents. Biochem. Biophys. Res. Commun. 357, 264-269

Larhammar D., 1996. Structural diversity of receptors for neuropeptide $\mathrm{Y}$, peptide $\mathrm{YY}$ and pancreatic polypeptide. Regul. Peptides $65,165-174$

Lawrence C.B., Snape A.C., Baudoin F.M.-H., Luckman S.M., 2002. Acute central ghrelin and $\mathrm{GH}$ secretagogues induce feeding and activate brain appetite centers. Endocrinology 143 , 155-162

Le Quellec A., Kervran A., Blache P., Ciurana A.J., Bataille D., 1992. Oxyntomodulin-like immunoreactivity: diurnal profile of a new potential enterogastrone. J. Clin. Endocrinol. Metab. 74, 1405-1409

Lectez B., Jeandel L., El-Yamani F.Z. et al., 2009. The orexigenic activity of the hypothalamic neuropeptide 26RFa is mediated by the neuropeptide $\mathrm{Y}$ and proopiomelanocortin neurons of the arcuate nucleus. Endocrinology 150, 2342-2350

Liddle R.A., Goldfine I.D., Rosen M.S., Taplitz R.A., Williams J.A., 1985. Cholecystokinin bioactivity in human plasma. Molecular forms, responses to feeding, and relationship to gallbladder contraction. J. Clin. Invest. 75, 1144-1152

Lin Y., Hall R.A., Kuhar M.J., 2011. CART peptide stimulation of G protein-mediated signaling in differentiated PC12 cells: identification of PACAP 6-38 as a CART receptor antagonist. Neuropeptides $45,351-358$

Liu Y.-L., Semjonous N.M., Murphy K.G., Ghatei M.A., Bloom S.R., 2008. The effects of pancreatic polypeptide on locomotor activity and food intake in mice. Int. J. Obesity $32,1712-1715$

Lo C.C., Davidson W.S., Hibbard S.K., Georgievsky M., Lee A., Tso P., Woods S.C., 2014. Intraperitoneal CCK and fourth-intraventricular apo AIV require both peripheral and NTS CCK1R to reduce food intake in male rats. Endocrinology 155, 1700-1707

Lopaschuk G.D., Ussher J.R., Jaswal J.S., 2010. Targeting intermediary metabolism in the hypothalamus as a mechanism to regulate appetite. Pharmacol. Rev. 62, 237-264

Maejima Y., Sedbazar U., Suyama S. et al., 2009. Nesfatin-1-regulated oxytocinergic signaling in the paraventricular nucleus causes anorexia through a leptin-independent melanocortin pathway. Cell Metab. 10, 355-365

Mercer A.J., Hentges S.T., Meshul C.K., Low M.J., 2013. Unraveling the central proopiomelanocortin neural circuits. Front. Neurosci. 7,19
Michel M.C., Beck-Sickinger A., Cox H., Doods H.N., Herzog H., Larhammar D., Quirion R., Schwartz T., Westfall T., 1998. $\mathrm{XVI}$. International Union of Pharmacology recommendations for the nomenclature of neuropeptide $Y$, peptide $Y Y$, and pancreatic polypeptide receptors. Pharmacol. Rev. 50, $143-150$

Minamino N., Kangawa K., Matsuo H., 1985. Neuromedin U-8 and U-25: novel uterus stimulating and hypertensive peptides identified in porcine spinal cord. Biochem. Biophys. Res. Commun. 130, 1078-1085

Mitchell J.D., Maguire J.J., Davenport A.P., 2009. Emerging pharmacology and physiology of neuromedin $U$ and the structurally related peptide neuromedin S. Brit. J. Pharmacol. 158, 87-103

Moran T.H., Baldessarini A.R., Salorio C.F., Lowery T., Schwartz G.J., 1997. Vagal afferent and efferent contributions to the inhibition of food intake by cholecystokinin. Am. J. Physiol. 272, R1245-R1251

Moran T.H., Kinzig K.P., 2004. Gastrointestinal satiety signals II. Cholecystokinin. Am. J. Physiol. Gastrointest. Liver Physiol. 286, G183-G188

Moriya R., Sano H., Umeda T., Ito M., Takahashi Y., Matsuda M., Ishihara A., Kanatani A., Iwaasa H., 2006. RFamide peptide QRFP43 causes obesity with hyperphagia and reduced thermogenesis in mice. Endocrinology 147, 2916-2922

Muccioli G., Lorenzi T., Lorenzi M., Ghè C., Arnoletti E., Raso G.M., Castellucci M., Gualillo O., Meli R., 2011. Beyond the metabolic role of ghrelin: A new player in the regulation of reproductive function. Peptides 32, 2514-2521

Nakazato M., Hanada R., Murakami N., Date Y., Mondal M.S., Kojima M., Yoshimatsu H., Kangawa K., Matsukura S., 2000. Central effects of neuromedin $U$ in the regulation of energy homeostasis. Biochem. Biophys. Res. Commun. 277, 191-194

Nakazato M., Murakami N., Date Y., Kojima M., Matsuo H., Kangawa K., Matsukura S., 2001. A role for ghrelin in the central regulation of feeding. Nature 409, 194-198

Nguyen A.D., Mitchell N.F., Lin S. et al., 2012. Y1 and Y5 receptors are both required for the regulation of food intake and energy homeostasis in mice. PLoS ONE 7, e40191, doi:10.1371/ journal.pone.0040191

Nonaka N., Shioda S., Niehoff M.L., Banks W.A., 2003. Characterization of blood-brain barrier permeability to $P Y Y_{3-36}$ in the mouse. J. Pharmacol. Exp. Ther. 306, 948-953

Oh-I S., Shimizu H., Satoh T. et al., 2006. Identification of nesfatin-1 as a satiety molecule in the hypothalamus. Nature 443 , 709-712

Okere B., Xu L., Roubos E.W., Sonetti D., Kozicz T., 2010. Restraint stress alters the secretory activity of neurons co-expressing urocortin-1, cocaine- and amphetamine-regulated transcript peptide and nesfatin- 1 in the mouse Edinger-Westphal nucleus. Brain Res. 1317, 92-99

Ozaki Y., Onaka T., Nakazato M., Saito J., Kanemoto K., Matsumoto T., Ueta Y., 2002. Centrally administered neuromedin U activates neurosecretion and induction of c-fos messenger ribonucleic acid in the paraventricular and supraoptic nuclei of rat. Endocrinology 143, 4320-4329

Pan W., Tu H., Kastin A.J., 2006. Differential BBB interactions of three ingestive peptides: obestatin, ghrelin, and adiponectin. Peptides 27, 911-916

Parker R.M.C., Herzog H., 1999. Regional distribution of Y-receptor subtype mRNAs in rat brain. Eur. J. Neurosci. 11, 1431-1448 
Peier A.M., Desai K., Hubert J. et al., 2011. Effects of peripherally administered neuromedin $U$ on energy and glucose homeostasis. Endocrinology 152, 2644-2654

Raddatz R., Wilson A.E., Artymyshyn R. et al., 2000. Identification and characterization of two neuromedin $U$ receptors differentially expressed in peripheral tissues and the central nervous system. J. Biol. Chem. 275, 32452-32459

Reeve J.R. Jr., Eysselein V.E., Ho F.J., Chew P., Vigna S.R., Liddle R.A., Evans C., 1994. Natural and synthetic CCK-58. Novel reagents for studying cholecystokinin physiology. Ann. N. Y. Acad. Sci. 713, 11-21

Rehfeld J.F., Bundgaard J.R., Friis-Hansen L., Goetze J.P., 2003. On the tissue-specific processing of procholecystokinin in the brain and gut - a short review. J. Physiol. Pharmacol. 54, 73-79

Robson A.J., Rousseau K., Loudon A.S., Ebling F.J., 2002. Cocaine and amphetamine-regulated transcript mRNA regulation in the hypothalamus in lean and obese rodents. J. Neuroendocrinol. 14, 697-709

Sakurai T., Amemiya A., Ishii M. et al., 1998. Orexins and orexin receptors: a family of hypothalamic neuropeptides and $G$ proteincoupled receptors that regulate feeding behavior. Cell 92, 573-585

Schjoldager B., Mortensen P.E., Myhre J., Christiansen J., Holst J.J., 1989. Oxyntomodulin from distal gut. Role in regulation of gastric and pancreatic functions. Diges. Dis. Sci. 34, 1411-1419

Schneeberger M., Gomis R., Claret M., 2014. Hypothalamic and brainstem neuronal circuits controlling homeostatic energy balance. J. Endocrinol. 220, T25-T46

Scott V., Kimura N., Stark J.A., Luckman S.M., 2005. Intravenous peptide $Y Y_{3-36}$ and $Y_{2}$ receptor antagonism in the rat: effects on feeding behaviour. J. Neuroendocrinol. 17, 452-457

Shimizu H., Oh-I S., Hashimoto K. et al., 2009. Peripheral administration of nesfatin-1 reduces food intake in mice: the leptinindependent mechanism. Endocrinology 150, 662-671
Takayasu S., Sakurai T., Iwasaki S. et al., 2006. A neuropeptide ligand of the $\mathrm{G}$ protein-coupled receptor GPR103 regulates feeding, behavioral arousal, and blood pressure in mice. Proc. Nat. Acad. Sci. USA 103, 7438-7443

Tang-Christensen M., Vrang N., Larsen P.J., 2001. Glucagon-like peptide containing pathways in the regulation of feeding behaviour. Int. J. Obes. Relat. Metab. Disord. 25, Suppl. 5, S42-S47

Verdich C., Flint A., Gutzwiller J.-P., Näslund E., Beglinger C., Hellström P.M., Long S.J., Morgan L.M., Holst J.J., Astrup A., 2001. A meta-analysis of the effect of glucagon-like peptide-1 (7-36) amide on ad libitum energy intake in humans. J. Clin. Endocrinol. Metab. 86, 4382-4389

Wortley K.E., Chang G.-Q., Davydova Z., Fried S.K., Leibowitz S.F., 2004. Cocaine- and amphetamine-regulated transcript in the arcuate nucleus stimulates lipid metabolism to control body fat accrual on a high-fat diet. Regul. Peptides 117, 89-99

Wynne K., Park A.J., Small C.J., Meeran K., Ghatei M.A., Frost G.S., Bloom S.R., 2006. Oxyntomodulin increases energy expenditure in addition to decreasing energy intake in overweight and obese humans: a randomised controlled trial. Int. J. Obesity 30, 1729-1736

Wynne K., Stanley S., McGowan B., Bloom S., 2005. Appetite control. J. Endocrinol. 184, 291-318

Xu M.M., 2015. Tolerability, safety, and pharmacokinetics of once weekly administration of long-acting GLP-1 analogue in healthy subjects. $75^{\text {th }}$ Scientific Sessions of the American Diabetes Association (ADA), Session 'Updates on GLP-1 Agonists', June $5-9,2015$, Boston, MA (USA) http://professional2. diabetes.org/presentations_details.aspx?congress $=238$

Zhang J.V., Ren P.-G., Avsian-Kretchmer O., Luo C.-W., Rauch R., Klein C., Hsueh A.J.W., 2005. Obestatin, a peptide encoded by the ghrelin gene, opposes ghrelin's effects on food intake. Science 310, 996-999

Zigman J.M., Jones J.E., Lee C.E., Saper C.B., Elmquist J.K., 2006. Expression of ghrelin receptor mRNA in the rat and the mouse brain. J. Comp. Neurol. 494, 528-548 